УДК 339.92:330.332

Кухарик Вікторія, кандидат економічних наук, асистент, Східноєвропейський національний університет імені Лесі Українки, кафедра міжнародних економічних відносин та управління проєктами м. Луцьк; ORCID ID: 0000-0003-3389-5181 e-mail: kucharyk.viktoria@eenu.edu.ua

https://doi.org/10.29038/2411-4014-2020-03-32-43

\title{
СУЧАСНІ ТЕНДЕНЦІЇ РОЗВИТКУ МІЖНАРОДНОЇ ІНВЕСТИЦІЙНОЇ ДІЯЛЬНОСТІ ТНК
}

В статті досліджено сучасні тенденції розвитку міжнародної інвестиційної діяльності ТНК. Визначено, що для успішного функціонування ТНК в приймаючій країні повинна бути стабільна політична ситуація $\mathrm{i}$ ефективна система регулювання бізнесу, що забезпечують інвестору, тобто ТНК, гарантію прав і захист інтересів. Серед чинників, що негативно впливають на інвестиційну діяльність ТНК є високий рівень корупції $\mathrm{i}$ нецільового використання коштів, складність ведення бізнесу, нестабліьна політична й економічна ситуація в країні. Окреслено однин із перспективних напрямів інвестиційної діяльності ТНК - fintech - новітня і стрімко зростаюча галузь глобальної економіки.

Ключові слова: ТНК, міжнародна інвестиційна діяльність, багатонаціональна корпорація, Fortune Global 500 , fintech

Кухарик Виктория, кандидат экономических наук, ассистент, Восточноевропейский национальный университет имени Леси Украинки, кафедра международных экономических отношений и управления проэктам м. Луцк

\section{СОВРЕМЕННЫЕ ТЕНДЕНЦИИ РАЗВИТИЯ МЕЖДУНАРОДНОЙ ИНВЕСТИЦИОННОЙ ДЕЯТЕЛЬНОСТИ ТНК}

В статье исследованы современные тенденции развития международной инвестиционной деятельности ТНК. Определено, что для успешного функционирования ТНК в принимающей стране должна быть стабильная политическая ситуация и эффективная система регулирования бизнеса, обеспечивающие инвестору, то есть ТНК, гарантию прав и защиту интересов. Среди факторов, негативно влияющих на инвестиционную деятельность ТНК выделено высокий уровень коррупции и нецелевого использования средств, сложность ведения бизнеса, нестаблиьна политическая и экономическая ситуация в стране. Определено одно из перспективных направлений инвестиционной деятельности ТНК - fintech - новейшая и быстро растущая отрасль глобальной экономики.

Ключевые слова: ТНК, международная инвестиционная деятельность, многонациональная корпорация, Fortune Global 500, fintech

Viktoriia Kukharyk, PhD in economics, Assistant, Lesia Ukrainka Eastern European National University, Department of International Economic Relations and Project Management

\section{CURRENT TRENDS OF TNC's INTERNATIONAL INVESTMENT ACTIVITIES DEVELOPMENT}

In today's world, the main subject of globalization are large transnational corporations (TNCs), which have a significant impact on the world economy development. The study of TNC investment processes plays an important role for economics.

The purpose of the paper is to highlighte the current trends of TNCs international investment activities. In 2018, the value of cross-border mergers and acquisitions (M\&A) increased by $18 \%$ due to the large size of transactions, 
especially in the chemical industry and services. The cost of the announced greenfield projects increased by $41 \%$, an increase mainly was in mining, processing and construction. Regarding the manufacturing sector, the net M\&A sales at the global level remained close to the 2017 level. Deal making in the pharmaceutical industry declined for the third successive year. M\&A sales have more than doubled in chemical industry. In services, net M\&A sales increased by over one third.

The article highlights that there must be a stable political situation and an effective system of business regulation that provide the investor, ie TNCs, a guarantee of rights and protection of interests for the successful operation of TNCs in the host country. High level of corruption and misuse of funds, the complexity of doing business, the unstable political and economic situation in the country are the factors that negatively affect on the investment activities of TNCs.

One of the promising areas of TNC investment activity is fintech - the newest and fastest growing sector of the global economy. Advanced achievements of scientific and technological progress, financial innovations, achievements and advantages of information, digital, network and intellectual components are concentrated in fintech today. ASEAN TNCs often merge fintech-start-ups and initiate fintech-departments to expand services and integrate financial technology into traditional businesses. Thus, the Malaysian bank CIMB Group in 2017 established a separate fintechdivision in order to find innovative banking solutions. The construction of a mobile banking platform in Vietnam and the Philippines, a mobile payment wallet developed with the participation of Chinese and Thai companies are the examples of such projects.

Keywords: TNCs, international investment activities, multinational corporation, Fortune Global 500, fintech.

Постановка проблеми та ії значення. Великі транснаціональні корпорації (ТНК), що здійснюють значний вплив на розвиток світової економіки є головним суб'єктом процесів глобалізації нині. Дослідження інвестиційних процесів ТНК відіграє важливу роль для економічної науки. Найважливішим джерелом зростання світової економіки є міграція транснаціонального капіталу, що також є стимулом розширення міжнародних економічних відносин. Нині, інвестиції ТНК є вагомим засобом забезпечення структурних зрушень в економікці країни, забезпечення технологічного прогресу, підвищення показників господарської діяльності тощо.

Аналіз останніх досліджень і публікацій. Дослідженням особливостей ТНК, сутності такої компанії, інвестиційної діяльності ТНК займалося чимало зарубіжних і вітчизняних вчених, зокрема: як Р. Вернон, Дж. Гелбрєйт, Дж. Даннінг, Р. Кейвз, Ч. Кіндлебергєр, П. Кругман, М. Міллер, М. Портер, А. Фрідман, К. Шарп, Дж. Сорос, О. Білорус, В. Білошапка, В. Будкін, Д. Лук’яненко, Ю. Макогон, В. Новицький, Т. Орєхова, І. Павленко, І. Рогач, В. Рокоча, С. Хаймер, О. Шнирков, С. Якубовський та інші.

В. Герасимчук, досліджуючи ТНК, виділяє такі їх типи: горизонтально-інтегровані корпорації 3 підприємствами, що випускають велику частину продукції (виробництво автомобілів у США або мережа підприємств «Fast Food»), вертикально-інтегровані корпорації, що об'єднують при одному власнику i під єдиним контролем найважливіші сфери у виробництві кінцевого продукту; диверсифіковані транснаціональні корпорації, що містять у собі національні підприємства 3 вертикальною і горизонтальною інтеграцією [2].

I. Давидова, К. Величко, О. Печенка досліджують фактори, якими керуються ТНК приймаючи інвестиційні рішення й обираючи країну для реалізації інвестиційного проекту [9].

Дослідженням позитивних та негативних аспектів впливу інвестиційної діяльності ТНК на національну економіку займалися такі вітчизняні дослідники, як Руденко Л., Терехов С., Прокопенко О., Федоренко В., [5, 6, 7].

Даннінг Дж. вивчає як у своїй діяльності ТНК використовують ділові теорії [21]. Віллем Ян Ламмерс займався досідженням шляху розвитку інвестицій ТНК, як саме вони розробляють політику прямих іноземних інвестицій [29].

Мета і завдання статті - дослідити вплив інвестиційної діляьності ТНК на економіку приймаючої країни; визначити сучасні тенденції розвитку міжнародної інвестиційної діяльності ТНК; окреслити проблеми залучення прямих інвестицій ТНК; обгрунтувати пріоритетні напрями активізації інвестиційних процесів ТНК.

Виклад основного матеріалу та обгрунтування отриманих результатів дослідження. Нині, ТНК відіграють важливу роль у процесах розширення та поглиблення світогосподарських зв'язків і міжнародного поділу праці, а також здійснюють як позитивний, та кі негативний вплив на економіки 
багатьох країн світу. Вони виступають провідним сполучним елементом як між національною та світовою економікою, так і між різними сегментами регіональних ринків.

Значне зростання процесу транснаціоналізації світової економіки в останні десятиліття зумовлено величезним масштабом операцій ТНК. Гостра конкурентна боротьба, пошук шляхів доступу до дешевих ресурсів і факторів виробництва змушує ТНК розширювати ринки для інвестування [4, с. 122].

Оцінюючи вплив ТНК на динаміку світового економічного розвитку виділяємо кілька основних напрямків:

1. Формування динаміки, структури та рівня конкурентоспроможності економіки на світовому ринку товарів і послуг.

2. Контроль міжнародного руху капіталу та прямих іноземних інвестицій, оскільки ТНК $є$ основним інвестором в країни, що розвивається, й досить відчутно впливають на їхній економічний розвиток.

3. Прискорення створення та передачі інновацій, концентруючи їх у своїх наукових центрах $\mathrm{i}$ підприємствах. Завдяки виробничим і фінансовим можливостям ТНК сконцентрували у своїх руках найбільш наукоємні виробництва. Вони ж виробляють найновіші види продукції 3 найбільш затребуваними споживачами характеристиками, тим самим сприяють процесу технологічного розвитку виробництва.

4. Розширення i прискорення міжнародної трудової міграції, сприяння розповсюдженню професійних знань, процесу обміну досвідом між співробітниками із різних країн і руху робочої сили слідом за прямими іноземними інвестиціями. Тим самим створюється міжнародний ринок праці, до якого характерною рисою є конвергенція професійної підготовки персоналу [15, с. 59-60].

Приймаючи інвестиційні рішення й обираючи країну для реалізації інвестиційного проекту, ТНК керуються такими факторами: стан виробничих фондів та їх ринкова перспективність; ступінь ефективності менеджменту; наявність експортного потенціалу чи унікальної продукції; наявність стабільного попиту на типову для підприємства продукцію на внутрішньому ринку; можливість реструктуризації об'єкта та його пристосування до вимог ринку, споживачів; наявність конструктивних відносин із урядом та владними структурами; прозорість компанії; організаційноправова форма об'єктної фірми; ведення бухгалтерського обліку відповідно до західних стандартів $[9$, c. 117].

Інвестиційна діяльність ТНК може здійснювати як позитивний, так і негативний вплив на економіку країн. Серед позитивних моментів $\epsilon$ те, що ТНК сприяють оптимальному розподілу усіх видів ресурсів та оптимальному розміщенню виробництва, завдяки їм, активніше поширюються нові товари та технології. Окрім того, ТНК сприяють посиленню конкуренції підриваючи позиції місцевих монополій, а також вони сприяють розширенню міжнародної співпраці [7, с. 34].

До негативного впливу діяльності ТНК належать: небезпека перетворення країни-реципієнта в місце скидання застарілих і екологічно небезпечних технологій; захоплення ТНК найбільш розвинутих і перспективних сегментів промислового виробництва країни, що приймає капітал, та іiі науково-дослідних структур; нав'язування компаніям країни-реципієнта далеко не самих перспективних напрямів у системі розподілу праці в рамках ТНК; можливість масового відтоку іноземних інвестицій з економіки приймаючої їх країни, що може викликати закриття підприємств та виникнення пов'язаних з цим негативних явищ; відплив прибутку закордонної філії на фінансування внутрішнього інвестиційного процесу материнської компанії [5, с. 233].

Світову економічну могутність сконцентровано в «руках» 100 найбільших ТНК (Microsoft, General Electric, Exxon Mobil, Wai Mart Stores, Citigroup, Johnson\&Johnson, Royal Dutch/Shell, BP, IBM, Ford, Nestle, Phillip Morris), [25]. В цілому, у світі за даними UNCTAD, налічується близько 85 тис. ТНК з 810 тис. зарубіжних підрозділів. За останні 30 років кількість ТНК збільшилась у 12 разів (у 1970 р. було зареєстровано 7 тис. таких фірм, у 1990 р. - 24 тис., у 2012 р. -85 тис. ТНК), у яких задіяно більше як 75 млн. чоловік. При цьому на території промислово розвинених держав розміщується понад 80 \% материнських компаній і близько $33 \%$ філій, у країнах, що розвиваються, - відповідно 19,5 \% і майже 50 \%, у колишніх соціалістичних державах - приблизно 0,5 \% і 17 \% [13].

Журналом Fortune Global 500 проведено дослідження щодо найбільших компаній світу. 
Основним критерієм складання списку служить доходи учасників. За цим показником рейтинг 2019 p. очолила американська ТНК Walmart, обсяг виручки якої становить 514,405 млрд. дол. США, а чистий прибуток - 6,670 млрд. дол. США [27], (табл.1.).

Таблиия 1.

ТОП-15 ТНК світу за версією журналу Fortune у 2019 р. (млрд. дол. США)

\begin{tabular}{|l|l|l|l|c|l|}
\hline Miсце & \multicolumn{1}{|c|}{ Компанія } & Доходи & Прибуток & $\begin{array}{c}\text { Зміна в } \\
\text { рейтингу }\end{array}$ & Країна базування \\
\hline 1. & Walmart & 514,405 & 6,670 & - & США \\
\hline 2. & Sinopec Group & 414,649 & 5,845 & 1 & Китай \\
\hline 3. & Royal Dutch Shell & 396,556 & 23,352 & 2 & Нідерланди \\
\hline 4. & China National Petroleum & 392,976 & 2,270 & - & Китай \\
\hline 5. & State Grid & 387,056 & 8,174 & -3 & Китай \\
\hline 6. & Saudi Aramco & 355,905 & 110,974 & - & Саудівська Аравія \\
\hline 7. & ВP & 303,738 & 9,383 & 1 & Великобританія \\
\hline 8. & Exхоn Mobil & 290,212 & 20,840 & 1 & США \\
\hline 9. & Volkswagen & 278,341 & 14,322 & -2 & Німеччина \\
\hline 10. & Тoyota Motor & 272,612 & 16,982 & -4 & Японія \\
\hline 11. & Apple & 265,595 & 59,531 & - & США \\
\hline 12. & Berkshire Hathaway & 247,837 & 4,021 & -2 & США \\
\hline 13. & Amazon.com & 232,887 & 10,073 & 5 & США \\
\hline 14. & UnitedHealth Group & 226,247 & 11,986 & 1 & США \\
\hline 15. & Samsung Electronics & 221,579 & 39,895 & -3 & Пд. Корея \\
\hline \multicolumn{2}{|l}{ Джерело: складено автором за [27]. } & & & \\
\hline & & & & \\
\hline
\end{tabular}

Walmart - це багатонаціональна корпорація роздрібної торгівлі в США, яка працює як мережа дисконтних універмагів та складських магазинів. Компанія має понад 11700 локацій по всьому світу i $\epsilon$ найбільшою в світі компанією за доходами. Окрім того, Walmart $\epsilon$ найбільшим приватним роботодавцем у світі з понад 2,2 млн. працівників.

Вже декілька десятків років лідером серед країн базування з найбільшими ТНК є США - 121 компанії 3 500. Друге місце дісталося Китаю - 119 компаній. Замикає трійку лідерів Японія - 52 компаній. Потім йдуть Франція - 31 компанія, Німеччина - 29 та Великобританія - 17 компаній (рис. 1.):

Таким чином, найбільш розвинені країни світу є країнами базування відповідають найбільших ТНК. Капітал, що мають ТНК (транснаціональний капітал), залучається в інші країни для розвитку власної системи виробництва та збуту, для реалізації ресурсної бази (в тому числі дешевшої, ніж в країні базування робочої сили). Інвестиційні потоки, що надходять 3 міжнародних компаній для модернізації чи розвитку будь-якої сфери $-\epsilon$ одним 3 перших кроків експансії національної економіки та реалізації зовнішньої політики ТНК. 3 одного боку, прямі іноземні інвестиції дають поштовх до розвитку промислових галузей, 3 іншого - отримані прибутки надходять до материнських компаній, виснажуючи ресурси приймаючих країн [14].

Розглянемо, як реалізовують ТНК свої інвестиційні стратегії на сучасному етапі розвитку.

Так, у 2018 р. вартість чистих транскордонних ЗіП зросла на 18 \% до 816 млрд. дол. США, відновившись після падіння на $22 \%$ у попередньому році. Це зростання було зумовлене великими розмірами угод, особливо в хімічній промисловості та сфері послуг. 


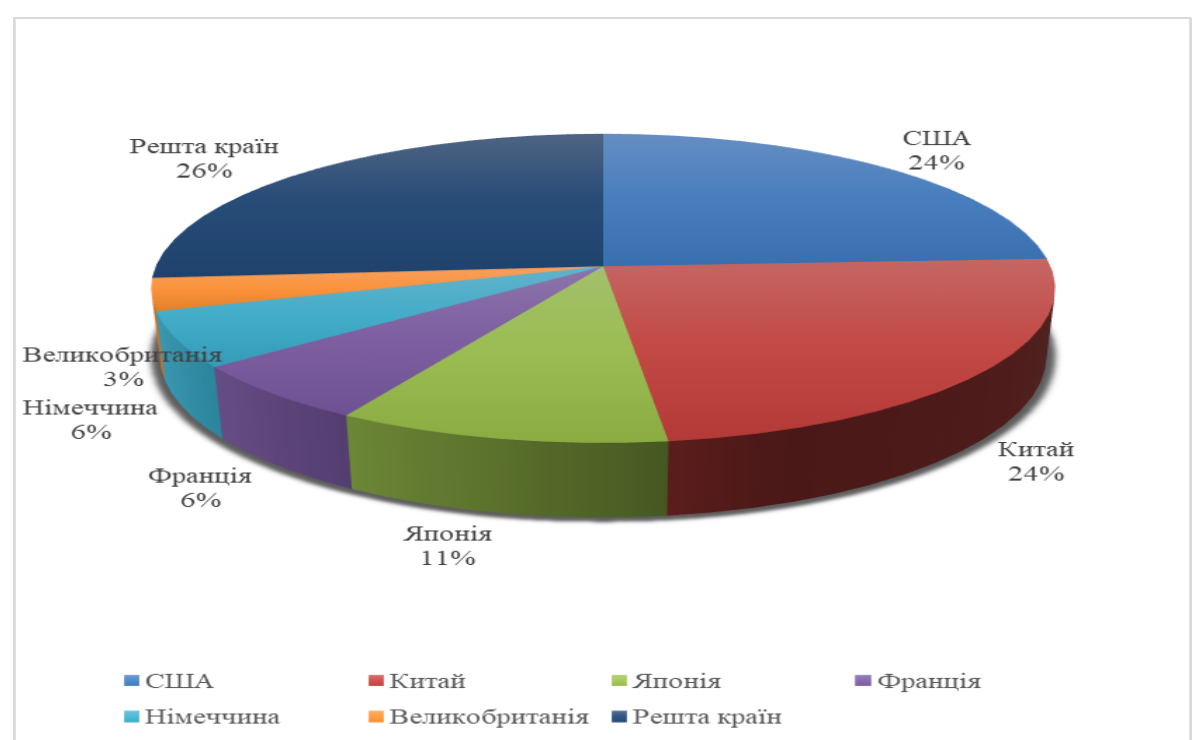

Рис.1. Розподіл топ 500 найбільших THК по краӥнам базування, (\%)

Джерело: складено автором за [27].

Вартість оголошених проектів «зеленої зони» (greenfield) зросла на $41 \%$ до 981 млрд. дол. США. Тут також середній розмір проектів був головним чингником зростання, оскільки інвестиційна активність, виміряна кількістю проектів, зросла лише на $7 \%$. Приріст переважно був у добувній та переробній галузях, а також у будівництві [30, с.7].

Значення глобальних чистиз ЗіП, виражене у відсотках до надходження ПІІ, становить $62 \%$, це найвищий рівень після 2000 р. У країнах, що розвиваються та в країнах з перехідною економікою, чистий обсяг продажів, пов'язаних з ЗіП, залишився стабільним і становить 127 млрд. дол. США. Зростання було зумовлене, головним чином, подвоєнням поглинять з боку ТНК США, що повязано зі зняттям податкових зобов'язань за накопиченими нерозподіленими прибутками за кордоном після податкової реформи $2017 \mathrm{p}$.

У первинному секторі найбільшою угодою було придбання компанією Total (Франція) виробника нафти і газу Maersk Olie og Gas (Данія) на суму 7,4 млрд. дол. США. Щодо виробничої сфери, то тут чистий обсяг продажів з ЗіП на світовому рівні залишився близьким до рівня 2017 p. Здійснення угод у фармацевтичній промисловості, яка в 2015 р. досягла 113 млрд. дол. США, знижується вже третій рік поспіль до 28 млрд. дол. США. У хімічній промисловості ЗіП збільшилися більш ніж удвічі, до 149 млрд. дол. США. Вони включали об'єднання Bayer (Німеччина) з Monsanto (США) вартістю 57 млрд. дол. США, а також Praxair (США) з групою Linde (Німеччина) на суму 32 млрд. дол. США.

Чистий продаж ЗіП у сфері послуг збільшився більш ніж на третину до 469 млрд. дол. США. Основним чинником є збільшення вартості ЗіП у фінансовій галузі майже вдвічі, до 108 млрд. дол. США. У цій галузі особливо великою була кількість інвестицій в нерухомість. Окремо, чистий обсяг продажів з ЗіП в сфері нерухомості в 2018 р.становив 57 млрд. дол. США. Інвестиції, пов'язані 3 нерухомістю, становили значну частину транскордонних ЗіП в 2018 р. Майже всі угоди в інвестиційні цільові фонди та три чверті угод 3 активами, орієнтованими на нерухомість, у розвинених країнах.

Загальна вартість проектів «зеленої зони» в первинному секторі зросла вдвічі, до 41 млрд. дол. США, в основному за рахунок проектів з видобутку металів, які в 2018 р. зросли до 20 млрд. дол. США, що є найвищим показником 32011 p. Karo Resources (Кіпр) оголосив про проект на суму 4,3 млрд. дол. США у платиновій шахті в Зімбабве, що підтримується корпорацією Africa Finance. Великі проекти були також оголошені в Чилі та Перу.

Задекларовані екологічні проекти у виробництві збільшилися на $35 \%$, до 466 млрд. дол. США. Наприклад, спільно з Shell Canada, спільним підприємством Shell, Petronas, PetroChina, Mitsubishi Corp. i Korea Gas розроблено проект щодо будівництва споруду для експорту скрапленого природного газу в Канаді, що є найбільшим проектом, оскільки заплановані капітальні витрати 
становлять 30 млрд. дол. США [30, с.10].

У країнах, що розвиваються, вартість оголошених проектів у виробництві зросла на $68 \%$ до 271 млрд. дол. США. Однак проекти залишаються зосередженими в Азії, де ПІІ у «зелену зону» у сфері виробництві подвоїлися до 212 млрд. дол. США. Наприклад, п'ять найбільших виробничих проектів у Китаї мали загальну вартість 33 млрд. дол. США, що є вдвічі більше порівняно 32017 р. Найбільшим проектом став план BASF (Німеччина) інвестувати 10 млрд. дол. США у нову хімічну виробничу базу в Чжаньцзяні. У цій же галузі ExxonMobil (США) оголосив про плани будівництва заводу етилену на 7 млрд. дол. США у місті Жушань.

У Саудівській Аравії Total (Франція) підписала меморандум про взаєморозуміння 3 Saudi Aramco щодо розробки нафтохімічного комплексу в Джубайлі в рамках проекту вартістю 9 млрд. дол. США. В Індії, Китайська провінція Тайваню оголосила про свій план інвестувати 6,6 млрд. дол. США у нафтохімічний проект у Парадипі.

Позитивна динаміка спостерігається і в Африці, де інвестиції у виробництво зросли на 60 \%, до 33 млрд. дол. США [30, с.11].

Загальний обсяг екологічних проектів у сфері послуг збільшився на $43 \%$ до 473 млрд. дол. США. Деякі $з$ цих проектів пов'язані з будівництвом спеціальних економічних зон. Наприклад, у 2015 р. дочірня компанія Nippon Steel та Sumikin Bussan (Японія), оголосили про проект розвитку спеціальної економічної зони Dawei в М'янмі. У 2016 р. Вей Ю Інжиніринг (Китайська провінція Тайваню) оголосила про плани інвестувати 2,5 млрд. дол. США в економічну зону Вунг-Анг у В'єтнамі для будівництва доків 3 логістичними районами та сільськогосподарськими районами. У 2018 р. виробник текстилю Shandong Ruyi Technology (Китай) оголосив про свій проект інвестувати 830 млрд. дол. США на створення текстильної промислової зони в економічній зоні Суецького каналу в Сгипті.

Проекти «зеленої зони» у виробництві електроенергії зросли на 23 \% у 2018 р. до 110 млрд. дол. США, що складає майже всі проекти у сфері комунальних послуг. В останнє десятиліття цінність проектів «зелених зон» у відновлюваній електроенергії перевищувала щорічне вироблення електроенергії на викопному паливі. У 2018 р. капітальні витрати на відновлювану електроенергію становили 78 млрд. дол. США. У країнах, що розвиваються, капітальні витрати на проекти «зеленої зони» 3 виробництва електроенергії (всі види) склали 70 млрд. дол. США [30, с.11].

Що стосується 2019 р., то згідно з даними Mergermarket обсяг ЗіП значно уповільнився у третьому кварталі цього року. Проте, незважаючи на уповільнення, у 2019 р. було здійснено декілька масштабних угод. Таким чином, протягом перших трьох кварталів 2019 р. було здійснено ЗіП на суму 2,49 трлн. дол. США, але ця сума знизилася на 11,4 \% від рівня обсягу угод, що спостерігався в цей час 2018 p.

У табл. 2. наведено 5 найбільших мегазлиттів у 2019 р.

Таблиия 2

5 найбільших мегазлиттів у 2019 р.

\begin{tabular}{|l|l|l|c|}
\hline $\begin{array}{c}\text { № } \\
\text { з/п }\end{array}$ & \multicolumn{1}{|c|}{ ТНК, країни } & \multicolumn{1}{|c|}{ Сектор } & $\begin{array}{c}\text { Вартість угоди, } \\
\text { млрд. дол. } \\
\text { США }\end{array}$ \\
\hline 1. & Bristol-Myers Squibb (США) + Celgene (США) & Фармацевтика & 89,5 \\
\hline 2. & United Technologies (США) + Raytheon (США & Оборона & 88,9 \\
\hline 3. & AbbVie (США)+ Allergan (Ірландія) & Фармацевтика & 86,3 \\
\hline 4. & $\begin{array}{l}\text { Saudi Aramco (Саудівська Аравія) + Saudi } \\
\text { Basic Industries Corporation (Саудівська } \\
\text { Apaвiя) }\end{array}$ & $\begin{array}{l}\text { Промисловість } \\
\text { та хімікати }\end{array}$ & 70,4 \\
\hline 5. & $\begin{array}{l}\text { Occidental Petroleum (США) + Anadarko } \\
\text { Petroleum (США) }\end{array}$ & Енергетика & 54,4 \\
\hline
\end{tabular}

Джерело: складено автором за [28].

Динаміка і структура транскордонних злиттів та поглинань засвідчує, що основними лідерами $€$ компанії найбільш розвинутих країн. Однак останнім часом поступово збільшується кількість операцій злиття та поглинання у країнах, що розвиваються. Даний вид угод стає важливим джерелом 
іноземних інвестицій та дає можливість побачити подальше зростання транснаціоналізації економіки цих країн. Виокремлення галузевого аналізу свідчить про зростання кількості угод злиття та поглинання в таких секторах як фармацевтика і енергетика. Також спостерігається активність у сфері послуг, хімічні промисловості, телекомунікаційному секторі. Галузеві особливості злиттів та поглинань визначають напрям діяльності ТНК, їх стратегічне позиціонування в цих галузях.

ТНК реалізують свої стратегічні цілі розвитку через інвестиції в інші країни. Прихід ТНК у певну країну та вихід національних корпорацій на зовнішні товарні і фінансові ринки - це економічне явище, яке має назву «транснаціоналізація» економіки. Воно сприяє інтеграції економіки певної країни у світову економіку, тобто залученню у процес глобалізації. Важливо, що ПІІ $є$ основним способом поширення впливу ТНК на національні економіки, а також $€$ засобом формування самих ТНК і глобальних стратегічних альянсів. А відтак транснаціоналізація економіки $€$ об'єктивним явищем, до якого кожна країна повинна виробити свою національну політику регулювання інвестиційного клімату на засадах власних національних інтересів [11].

Отже, ТНК володіють величезними фінансовими, виробничими і технологічними ресурсами, використовуючи які вони самі і їх філії впливають на економіку приймаючої країни. Ступінь цього впливу визначається масштабами капіталу, що залучається, його галузевою структурою, а також залежить від інвестиційного клімату в країні та зацікавленості в залученні іноземного капіталу.

Для успішного функціонування ТНК в приймаючій країні повинна бути стабільна політична ситуація і ефективна система регулювання бізнесу, що забезпечують інвестору, тобто ТНК гарантію прав і захист інтересів. Серед чинників, що негативно впливають на інвестиційну діяльність ТНК $\epsilon$ високий рівень корупції і нецільового використання коштів, складність ведення бізнесу, нестабліьна політична й економічна ситуація в країні.

Держава повинна створити позитивні умови, для стимулювання залучення ПІІ ТНК, а саме:

- удосконалити системи оподаткування та нарахування амортизації;

- сформувати особливий податковий режим;

- запровадити пільгові умови використання природних ресурсів;

- розвивати лізингові операції;

- запровадити систему регулярної переоцінки основних фондів підприємств [10].

Держава, що приймає інвестиції повинна забезпечити мирне співіснування іноземних i національних інвесторів, удосконалити систему захисту від ризиків (в тому числі і політичного характеру), справедливу систему врегулювання інвестиційних суперечок, а також не повинна перешкоджати репатріації прибутку (вивезення прибутку в свою країну для іноземного інвестора), [16].

Таким чином, для того щоб активізувати інвестиційну діяльність, ТНК необхідно забезпечувати роботу чітких, зрозумілих та зручних механізмів іiі реалізації як на регіональному, так і на державному рівнях. А для цього перш за все уряд повинен займатися розробкою національних та регіональних стратегій розвитку, які б займалися дослідженням та забезпеченням бажаного економічного ефекту на довгостроковій основі завдяки координації роботи органів управління державою та органів місцевого самоврядування [3].

3 метою запобігання монополізації, контролю за правомірністю та впливу інших регулюючих заходів країна повинна прийняти відповідні законодавчі акти, які обмежували б діяльність ТНК і спрямовували їх у сфери, визначені державою як пріоритетні. При цьому місцевим підприємствам варто співпрацювати 3 іноземними ТНК не в якості джерела дешевих сировинних ресурсів або відсталого технологічного придатку, а використовувати переваги залучення іноземних інвестицій для розвитку свого інноваційного потенціалу [8, с. 722]

Для того, щоб оздоровити інвестиційний клімат країни та сприяти припливу ПІІ ТНК пропонуємо ряд заходів, що стосуються змін в інвестиційних процесах.

Насамперед, необхідно забезпечити можливість інформаційного і фінансового контролю за використанням ресурсів інвестора в режимі online, віддаленого на будь-яку відстань від місця вкладення ресурсів. Для обслуговування інвестицій варто створити інтегровану інвестиційну інфраструктуру, інтегруючи банківську, законодавчу та організаційну структури. На регіональному та галузевому аспектах потрібно розробити і реалізувати інтегральні механізми і технології управління інвестиційними процесами. Варто розробити, затвердити та здійнювати фінансування 
інвестиційних проектів країни спільно з ТНК, а також інвестиційних проектів, що фінансуються за рахунок коштів бюджетів усіх рівнів (державно-приватне партнерство).

Не менш важливим є забезпечення державних гарантій всім суб'єктам інвестиційної діяльності незалежно від форм власності: рівних прав при здійсненні інвестиційної діяльності; гласність при обговоренні інвестиційних проектів і право оскарження в судовому порядку будь-яких рішень, дій (бездіяльності) органів державної влади, органів місцевого самоврядування та їх посадових осіб. Окрім того, потрібно забезпечити й стабільність прав суб'єкта інвестиційної діяльності. У випадках прийняття законів, що встановлюють для суб'єктів інвестиційної діяльності інші правила, ніж ті, які діяли при укладенні договорів між ними, умови цих договорів зберігають свою силу, за винятком випадків, коли законом встановлено, що його дія поширюється на відносини, що виникають з раніше укладених договорів [12].

Необхідно здіійснювати комплексне обслуговування самого інвестора (ТНК), його інвестиційного інституту, реципієнтів інвестицій; забезпечувати інвестиційних інститутів на інформаційному ринку, аналітичне та експертне забезпечення їх проектів і програм, організаційний супровід проектів.

Варто орієнтувати інвестиційні інститути на формування умов для проникнення іноземного капіталу і створювати сприятливі умови для такого проникнення, а саме: страхування інвестиційних ризиків, облік різниці валютних ставок національних валют, довгостроковість надання інвестиційних ресурсів, ліквідність заставних активів і наданих гарантій тощо.

ТНК перетворились на важливі центри прийняття рішень у світовому масштабі. Створюючи глобальні виробничі і торговельні імперії, вони активно впливають на розвиток світової економіки в цілому. Зростаюча глобалізація економічного життя на рівні ТНК все більше вимагатиме відповідної макроекономічної політики на державному рівні.

Одним із перспективних напрямів інвестиційної діяльності ТНК вважаємо fintech - це новітня i стрімко зростаюча галузь глобальної економіки, у якій на сьогодні найбільш яскраво сконцентровані передові досягнення науково-технологічного прогресу, фінансові інновації, здобутки і переваги інформаційної, цифрової, мережевої та інтелектуальної складових глобальної економіки.

Спеціалісти Ernst\&Young визначають fintech як швидкозростаючі організації, що поєднують інноваційні бізнес-моделі та техно-логії для функціонування, покращення та руйнування фінансової системи [19, с. 11].

За версією Fintech Weekly, поняттям «fintech» можна назвати будь-яку компанію, що намагається надавати фінансові послуги, використовуючи програмне забезпечення та сучасні технології [22].

За своєю сутністю fintech є масштабним фінансовотехнологічним стартапом, який здатний в недалекому майбутньому кардинально змінити архітектоніку глобального ринку фінансовоінвестиційних послуг і навіть призвести до формування глобального альтернативного ринку капіталу. Так, у дослідженні Всесвітнього економічного форуму, зазначається, що фінансовотехнологічні стартапи за останні два-три роки суттєво вплинули на діяльність традиційних гравців ринку фінансово-інвестиційних послуг i, головне, вони визначили перспективні напрями свого розвитку, окреслили формат і динаміку інновацій в ключових сферах ринку фінансових послуг, досягли усталеності свого бізнесу i високої залученості в глобальні ланцюги фінансовоінвестиційного процесу [20].

Експерти вважають, що такі глобальні технологічні корпорації, як Facebook, Google, Amazon, Alibaba складають транснаціональним фінансово-інвестиційним компаніям і банкам значні конкурентні загрози, єдиним варіантом протидії яким є швидка адаптація ними технологій fintech у свою традиційну діяльність, мінімізуючи таким чином негативні наслідки конкурентної боротьби на ринку інноваційних фінансових послуг. У цьому контексті розвиток fintech як одного 3 методів креативізації фінансово-інвестиційних процесів підтверджує сформульовану нами тезу про одночасну функціональну спрямованість креативізації як на усталені форми провадження інвестиційного бізнесу, так і креативноінноваційні із застосуванням креативного інвестиційного інструментарію, креативних технологій і креативного процесінгу [1, с. 44].

На хвилі новітніх трендів світові інвестиції у сферу fintech відреагували стрімким зростанням у 2018 р., сягнувши 57,9 млрд. дол. США порівняно з 38,2 млрд. дол. США, інвестованими за весь 
2017 p., [24].

Основою досягнення нового максимуму стали 9 мега-угод на суму більше, ніж 1 млрд. дол. США, а також масштабною серією додаткового фінансування, здійсненого рядом перспективних азійських компаній з Китаю, Японії, Індії, Австралії та Сінгапуру. При цьому інвестиційні потоки в галузь fintech формувались як у вигляді ПII, так і за рахунок венчурних інвестицій та угод ЗіП [1, с. 45].

Серед fintech-компаній вже з'явилися свої «Є динороги» - компанії вартістю більше ніж 1 млрд. дол. США. Основними напрямками, в яких стрімко розвивають свій бізнес такі стартапи, $\epsilon$ :

- платежі - Ant Financial, Stripe, Mozido, Klarna, Transferwise;

- кредитування - SoFi, Kabbage, Lufax, Prosper, Funding Circle [17].

Інвестиції у індустрії, що розвиваються, серед яких і fintech, становлять все більший інтерес для американських, китайських, японських, німецьких ТНК [18].

Так, наприклад, ТНК з країн АСЕАН часто поглинають fintech -стартапи та започатковують fintech-департаменти задля розширення послуг та інтеграції фінансових технологій у традиційний бізнес. Так, малазійський банк CIMB Group у 2017 р. заснував окремий fintech-підрозділ 3 метою пошуку інноваційних банківських рішень. Серед проектів $\epsilon$ побудова мобільної банкінг-платформи у В'єтнамі та Філіппінах та платіжний мобільний гаманець, розроблений за участі китайських та тайських партнерських компаній. Аналогічні проекти запустили також Union Bank, Globe Telecom, JG Summit Group, Grab [23].

Важливою ланкою fintech-системи АСЕАН є акселератори, бізнесінкубатори та інноваційні лабораторії, що, як і стартапи, здебільшого сконцентровані у Сінгапурі (52 од.), В'єтнамі (24 од.), Індонезії (20 од.) та Малайзії (5 од.), [26].

Висновки та перспективи подальших досліджень. Таким чином, на розвиток інвестиційних процесів ТНК дедалі більше починає впливати глобальна технологізація економічної діяльності шляхом всепроникаючої інформатизації, цифровізації, мережевізації і роботизації традиційних фінансово-інвестиційних сервісів i бізнесів. Рушійною силою цього процесу $\epsilon$ зростаюча зацікавленість ТНК в пошуку нових креативних інвестиційних пропозицій в глобальному середовищі, які дозволяють підвищити ефективність інвестицій. Такими можливостями нині володіє, насамперед, зростаючий фінансово-технологічний та інвестиційно-креативний сегменти глобальної економіки.

\section{Джерела та література}

1. Бурмака М. Креативізація глобального інвестиційного процесу. Міжнародна економічна політика. 2018. № 2(29). С. 37-54.

2. Гайдуцький І. П. Розвиток транснаціональних корпорацій (ТНК) та їхній вплив на економіку країн. Економіка АПК. 2008. №1. С. 53-58.

3. Кочетков В.М. Розвиток українських ТНК як фактор росту економіки країни. Ефективна економіка. 2013. № 10. C. 55-60.

4. Немировська О.В. Механізм регулювання взаємодії національної економіки з транснаціональними корпораціями. Економіка та держава. 2015. № 12. С. 121-125.

5. Руденко Л. В. Управління потоками капіталів у сучасній бізнес-моделі функціонування транснаціональних корпорацій. Журнал Свропейської економіки. 2009. Т. 8. № 2. С. 232-233.

6. Терехов Є.М., Прокопенко О.В. Вплив транснаціональних корпорацій на розвиток національних економічних систем. Вісник Сумського держсавного університету: Сер. «Економіка». 2010. № 1. С. 103-113.

7. Федоренко В.Г. Транснаціональні корпорації як системоутворюючий фактор розвитку національних економік. Інвестиції: практика та досвід. 2009. № 7. С. 31-34.

8. Чумак Н. В. Проблемні аспекти діяльності транснаціональних корпорацій в Україні. Глобальні та національні проблеми економіки. 2016. № 9. С. 719-723.

9. Давидова І.О., Величко К.Ю., Печенка О.І. Транснаціональні корпорації. Харків: Видавництво «Форт», 2018. 175c. URL: http://elib.hduht.edu.ua/jspui/bitstream/123456789/2672/1/\%D0\%A2\%D0\%9D\%D0\%9A\%202\%D0\%B3\%D0\%B5\%20\%D0\%B2\%D0\%B8\%D0\%B4\%D0\%B0\%D0\%BD\%D0\%BD\%D1\%8F.pdf. (дата звернення $\underline{19.05 .2020)}$ 
10. Квон Г.М. Некоторые вопросы стратегического управления регионами: инвестиционный аспект. Вестник экономики, права и соииологии. 2012. № 4. C. 52-55. URL: https://cyberleninka.ru/article/n/nekotoryevoprosy-strategicheskogo-upravleniya-regionami-investitsionnyy-aspekt/viewer. (дата звернення 19.05.2020)

11. Кравечнок М.. Проблеми залучення прямих інвестицій транснаціональних корпорацій в економіку України. URL: http://personal.in.ua/article.php?ida=468. (дата звернення 20.05.2020)

12. Минлибаев, А. Д. Проблемы привлечения иностранных инвестиций в российскую экономику. URL: https://cyberleninka.ru/article/n/problemy-privlecheniya-inostrannyh-investitsiy-v-rossiyskuyu-ekonomiku/viewer (дата звернення 20.05.2020)

13. Офіційний сайт ЮНКТАД. URL: http://www.unctad.org (дата звернення 18.05.2020)

14. Побоченко Л. М. Аналіз інвестиційної діяльності транснаціональних корпорацій. Наукові журнали Національного Авіаційного університету. 2013. № 3. С. 120-127. URL: http://jrnl.nau.edu.ua/index.php/SR/article/view/7022. (дата звернення 19.05.2020)

15. Прохорова М. Е. Особливості формування впливу зарубіжних ТНК на Україну в XXI ст. Науковий вісник Інституту міжнародних відносин НАУ. Серія: економіка, право, політологія, туризм. 2011. № 4. С. 4955. URL: http://jrnl.nau.edu.ua/index.php/IMV/article/view/3261/3214 (дата звернення 18.05.2020)

16. Сусь Е. Е., Дудакова Л. Г. Влияние прямых иностранных инвестиций транснациональных корпораций на экономику принимающих стран. Молодой ученый. 2018. №13. C. 264-266. URL: https://moluch.ru/archive/199/48958. (дата звернення 19.05.2020)

17. ФIНТЕХ В УКРӒ̈НI: тенденції, огляд ринку та каталог. URL: https://data.unit.city/fintech/fgt34ko67mok/fintech in_Ukraine_2018 ua.pdf. (дата звернення 18.05.2020)

18. Annual Fintech Almanac: Financing and M\&A Statistics

URL: http://fpnpu.cibs.ubs.edu.ua/article/view/177100/177124. (дата звернення 18.05.2020)

19. Baldwin H., Gulamhuseinwala I. UK FinTech. On the cutting edge. URL: https://fintechauscensus.ey.com/2018/Documents/EY-UK-FinTech-On-the-cutting-edge.pdf. $\underline{20.05 .2020)}$

20. Beyond Fintech: A Pragmatic Assessment of Disruptive Potential in Financial Services. World Economic Forum, August 2017. URL: http://www3.weforum.org/docs/Beyond Fintech A_Pragmatic_Assessment_of_Disruptive_Potential_in_Financial_Services.pdf. (дата звернення 20.05.2020)

21. Dunning J.H., The electic paradigm as an envelope for economic and business theories of MNE activity. International Business Review. 1990. Vol. 9. $\quad$ P. $163-190 . \quad$ URL: https://pdfs.semanticscholar.org/55e1/aa8c94e7c8bee261555d4059a3552628a1a8.pdf. (дата звернення 18.05.2020)

22. Fintech definition. URL: https://www.fintechweekly.com/fintech-definition. (дата звернення 18.05.2020)

23. Hwee W. K., Kirollos K., Cecilia Salta M. ASEAN Investment Report 2018: Foreign Direct Investment and the Digital Economy in ASEAN. URL: https://asean.org/storage/2018/11/ASEAN-Investment-Report-2018-forWebsite.pdf. (дата звернення 19.05.2020)

24. Pulse of Fintech 2018. Global Analysis of Investment in Fintech. KPMG International, 31 July 2018. URL: https://assets.kpmg/content/dam/kpmg/it/pdf/2018/08/Pulse-of-Fintech-H118.pdf. (дата звернення 20.05.2020)

25. Sarumi Adewumi. The Impact of FDI on Growth in Developing Countries: An African Experience. Jönköpig, September 2012. 18 p. URL: https://pdfs.semanticscholar.org/5a79/2039bc0151eb4178916423d2a924358e2f63.pdf. (дата звернення 19.05.2020)

26. Soon L. N., Thung B. ASEAN FinTech Census 2018. URL: https://www.researchgate.net/publication/330702115_ASEAN_FinTech_Census_2018. (дата звернення 19.05.2020)

27. The Fortune 500. URL: https://fortune.com/global500/2019/search/. (дата звернення 18.05.2020)

28. These are the 5 largest mega-mergers so far in 2019. URL: https://markets.businessinsider.com/news/stocks/5-biggest-mega-mergers-of-2019-according-to-mergermarket-201910-1028578297\#1-bristol-myers-squibb-celgene5. (дата звернення 19.05.2020)

29. Willem Jan Lammers. The Investment Development Path: Is It Relevant For Designing Foreign Direct Investment Policies? URL: https://edepot.wur.nl/411387. (дата звернення 18.05.2020)
30. World
Investment
Report
2019.
World
Trade
Organization.
URL:

https://unctad.org/en/PublicationsLibrary/wir2019_en.pdf. (дата звернення 19.05.2020)

\section{References}

1. Burmaka M. (2018) Kreatyvizatsiia hlobalnoho investytsiinoho protsesu [Creativity of the global investment process]. Mizhnarodna ekonomichna polityka - International economic policy, 2(29), $37-54$ [in Ukrainian].

2. Haidutskyi I. P. (2008) Rozvytok transnatsionalnykh korporatsii (TNK) ta yikhnii vplyv na ekonomiku krain [Development of transnational corporations (TNCs) and their impact on the economy]. Ekonomika APK-Economics of agro-industrial complex, $1,53-58$ [in Ukrainian]. 
3. Kochetkov V.M. (2013) Rozvytok ukrainskykh TNK yak faktor rostu ekonomiky krainy [Development of Ukrainian TNCs as a factor of economic growth of the country], Efektyvna ekonomika - Efficient economy, 10, 55-60 [in Ukrainian].

4. Nemyrovska O.V. (2015) Mekhanizm rehuliuvannia vzaiemodii natsionalnoi ekonomiky z transnatsionalnymy korporatsiiamy [Mechanism for regulating the interaction of the national economy with transnational corporations], Ekonomika ta derzhava - Economy and state, 12, 121-125 [in Ukrainian].

5. Rudenko L. V.(2009) Upravlinnia potokamy kapitaliv u suchasnii biznes-modeli funktsionuvannia transnatsionalnykh korporatsii [Management of capital flows in the modern business model of multinational corporations], Zhurnal Yevropeiskoi ekonomiky - Journal of the European Economy, 2, 232-233 [in Ukrainian].

6. Terekhov Ye.M., Prokopenko O.V.(2010) Vplyv transnatsionalnykh korporatsii na rozvytok natsionalnykh ekonomichnykh system [The influence of transnational corporations on the development of national economic systems], Visnyk Sumskoho derzhavnoho universytetu: Ser. «Ekonomika»-Bulletin of Sumy State University: Ser. "Economy", 1, 103-113 [in Ukrainian].

7. Fedorenko V.H. (2009) Transnatsionalni korporatsii yak systemoutvoriuiuchyi faktor rozvytku natsionalnykh ekonomik [Transnational corporations as a system-forming factor in the development of national economies], Investytsii: praktyka ta dosvid-Investments: practice and experience, 7, 31-34 [in Ukrainian].

8. Chumak N. V. (2016) Problemni aspekty diialnosti transnatsionalnykh korporatsii v Ukraini [Problematic aspects of transnational corporations in Ukraine], Hlobalni ta natsionalni problemy ekonomiky - Global and national economic problems, 9, 719-723 [in Ukrainian].

9. Davydova I.O., Velychko K.Iu., Pechenka O.I. (2018) Transnatsionalni korporatsii [Transnational corporations]. Kharkiv: Vydavnytstvo $\quad$ «Fort». http://elib.hduht.edu.ua/jspui/bitstream/123456789/2672/1/\%D0\%A2\%D0\%9D\%D0\%9A\%202-

\%D0\%B3\%D0\%B5\%20\%D0\%B2\%D0\%B8\%D0\%B4\%D0\%B0\%D0\%BD\%D0\%BD\%D1\%8F.pdf. [in Ukrainian].

10. Kvon H.M. (2012) Nekotorye voprosy strategicheskogo upravlenija regionami: investicionnyj aspekt [Some issues of strategic regional management: investment aspect], Vestnik jekonomiki, prava i sociologii - Bulletin of Economics, Law and Sociology, 4, 52-55. Retrieved from::https://cyberleninka.ru/article/n/nekotorye-voprosystrategicheskogo-upravleniya-regionami-investitsionnyy-aspekt/viewer [in Russian].

11. Kravechnok M. Problemy zaluchennia priamykh investytsii transnatsionalnykh korporatsii $\mathrm{v}$ ekonomiku Ukrainy [Problems of attracting direct investment of transnational corporations in the economy of Ukraine] Retrieved from: http://personal.in.ua/article.php?ida=468. [in Ukrainian].

12. Minlibaev, A. D. Problemy privlechenija inostrannyh investicij v rossijskuju jekonomiku [Problems of attracting foreign investment in the Russian economy]. Retrieved from: https://cyberleninka.ru/article/n/problemyprivlecheniya-inostrannyh-investitsiy-v-rossiyskuyu-ekonomiku/viewer [in Russian].

13. Ofitsiinyi sait YuNKTAD [Official UNCTAD website]. Retrieved from:: http://www.unctad.org. [in English].

14. Pobochenko L. M. (2013) Analiz investytsiinoi diialnosti transnatsionalnykh korporatsii [Analysis of investment activities of transnational corporations], Naukovi zhurnaly Natsionalnoho Aviatsiinoho universytetu Scientific journals of the National Aviation University, 3, 120-127. Retrieved from: http://jrnl.nau.edu.ua/index.php/SR/article/view/7022. [in Ukrainian].

15. Prokhorova M. E. (2011) Osoblyvosti formuvannia vplyvu zarubizhnykh TNK na Ukrainu v 21 st. [Features of the formation of the foreign TNCs influence on Ukraine in the XXI century], Naukovyi visnyk Instytutu mizhnarodnykh vidnosyn NAU. Seriia: ekonomika, pravo, politolohiia, turyzm - Scientific Bulletin of the Institute of International Relations of NAU. Series: economics, law, political science, tourism, 4, 49-55. Retrieved from: http://jrnl.nau.edu.ua/index.php/IMV/article/view/3261/3214 [in Ukrainian].

16. Sus' E. E., Dudakova L. G. (2018) Vlijanie prjamyh inostrannyh investicij transnacional'nyh korporacij na jekonomiku prinimajushhih stran [Influence of foreign direct investment of transnational corporations on the economy of host countries], Molodoj uchenyj - A young scientist, 13, 264-266. Retrieved from: https://moluch.ru/archive/199/48958. [in Russian].

17. FINTEKh V UKRAINI: tendentsii, ohliad rynku ta kataloh [FINTECH IN UKRAINE: trends, market overview and catalog]. Retrieved from: https://data.unit.city/fintech/fgt34ko67mok/fintech_in_Ukraine_2018_ua.pdf. [in Ukrainian].

18. Annual Fintech Almanac: Financing and $M \& A$ Statistics. Retrieved from: http://fpnpu.cibs.ubs.edu.ua/article/view/177100/177124. [in English].

19. Baldwin H., Gulamhuseinwala I. UK FinTech. On the cutting edge. Retrieved from: https://fintechauscensus.ey.com/2018/Documents/EY-UK-FinTech-On-the-cutting-edge.pdf. [in English].

20. Beyond Fintech: A Pragmatic Assessment of Disruptive Potential in Financial Services. World Economic Forum, August 2017. Retrieved from: http://www3.weforum.org/docs/Beyond_Fintech__A_Pragmatic_Assessment_of_Disruptive_Potential_in_Financial_Services.pdf._[in English].

21. Dunning J.H. (1990) The electic paradigm as an envelope for economic and business theories of MNE 
activity. International Business $\quad$ Review, $\quad 9, \quad 163-190 . \quad$ Retrieved from: https://pdfs.semanticscholar.org/55e1/aa8c94e7c8bee261555d4059a3552628a1a8.pdf. [in English].

22. Fintech definition. Retrieved from: https://www.fintechweekly.com/fintech-definition. [in English].

23. Hwee W. K., Kirollos K., Cecilia Salta M. (2018) ASEAN Investment Report 2018: Foreign Direct Investment and the Digital Economy in ASEAN. Retrieved from: https://asean.org/storage/2018/11/ASEAN-Investment-Report2018-for-Website.pdf._[in English].

24. Pulse of Fintech 2018. Global Analysis of Investment in Fintech. KPMG International. Retrieved from: https://assets.kpmg/content/dam/kpmg/it/pdf/2018/08/Pulse-of-Fintech-H118.pdf._[in English].

25. Sarumi Adewumi (2012). The Impact of FDI on Growth in Developing Countries: An African Experience. Jönköpig. Retrieved from: https://pdfs.semanticscholar.org/5a79/2039bc0151eb4178916423d2a924358e2f63.pdf. [in English].

26. Soon L. N., Thung B. (2018) ASEAN FinTech Census. Retrieved from: https://www.researchgate.net/publication/330702115_ASEAN_FinTech_Census_2018. [in English].

27. The Fortune 500. Retrieved from: https://fortune.com/global500/2019/search/. [in English].

28. These are the 5 largest mega-mergers so far in 2019. Retrieved from: https://markets.businessinsider.com/news/stocks/5-biggest-mega-mergers-of-2019-according-to-mergermarket-201910-1028578297\#1-bristol-myers-squibb-celgene5. [in English].

29. Willem Jan Lammers. The Investment Development Path: Is It Relevant For Designing Foreign Direct Investment Policies? Retrieved from: https://edepot.wur.nl/411387. [in English].

30. World Investment Report 2019. World Trade Organization. Retrieved from: https://unctad.org/en/PublicationsLibrary/wir2019 en.pdf. [in English].

Стаття надійшла до редакції 02.07.2020 p. 